\title{
TRANSFORMING A CONTROVERSIAL HERITAGE: THE CASE OF THE FASCIST VICTORY MONUMENT IN SOUTH TYROL
}

\author{
ANDREA CARLÀ \\ EURAC RESEARCH - INSTITUTE FOR MINORITY RIGHTS \\ JOHANNA MITTERHOFER \\ EURAC RESEARCH - INSTITUTE FOR MINORITY RIGHTS
}

\begin{abstract}
Using a Fascist monument in South Tyrol, Northern Italy as a case study, this paper investigates the role of monuments in managing and negotiating interpretations of the past in culturally heterogeneous societies. It explores approaches to overcoming the exclusionary potential of cultural heritage, reframing it in more inclusive, pluralist terms. It provides an in-depth analysis of a dialogical, pluralistic approach to heritage, which allows divergent, even contrary, interpretations of the past to coexist. Thus, the paper sheds light on how monuments (re)construct and contest memory and history. It provides insights into constructive ways of engaging with a controversial heritage in multiethnic societies.
\end{abstract}

Keywords: cultural heritage; fascism; memory; monuments; reconciliation; South Tyrol; multiethnic societies

DOI: $10.14712 / 23363231.2018 .1$

\section{Introduction}

The Victory Monument in Bolzano/Bozen, a town in the province of South Tyrol in northern Italy, immediately reminds the visitor of the fascist period in which it was erected. Its columns resemble the lictoral fasces, which later became a model for a key element of fascist architecture. An inscription in Latin reads,

Dr. Andrea Carlà and Johanna Mitterhofer are researchers at the Institute for Minority Rights of Eurac Research in Bolzano/Bozen. Address correspondence to Dr. Andrea Carlà, Institute for Minority Rights, Eurac Research, Viale Druso 1, 39100 Bolzano/Bozen, Italy.

E-mail: andrea.carla@eurac.edu. 
"Here at the border of the Fatherland, plant the insignia/From here we educated the others with language, law and the arts." The monument is an embodiment of fascist ideology (see Fig. 1).

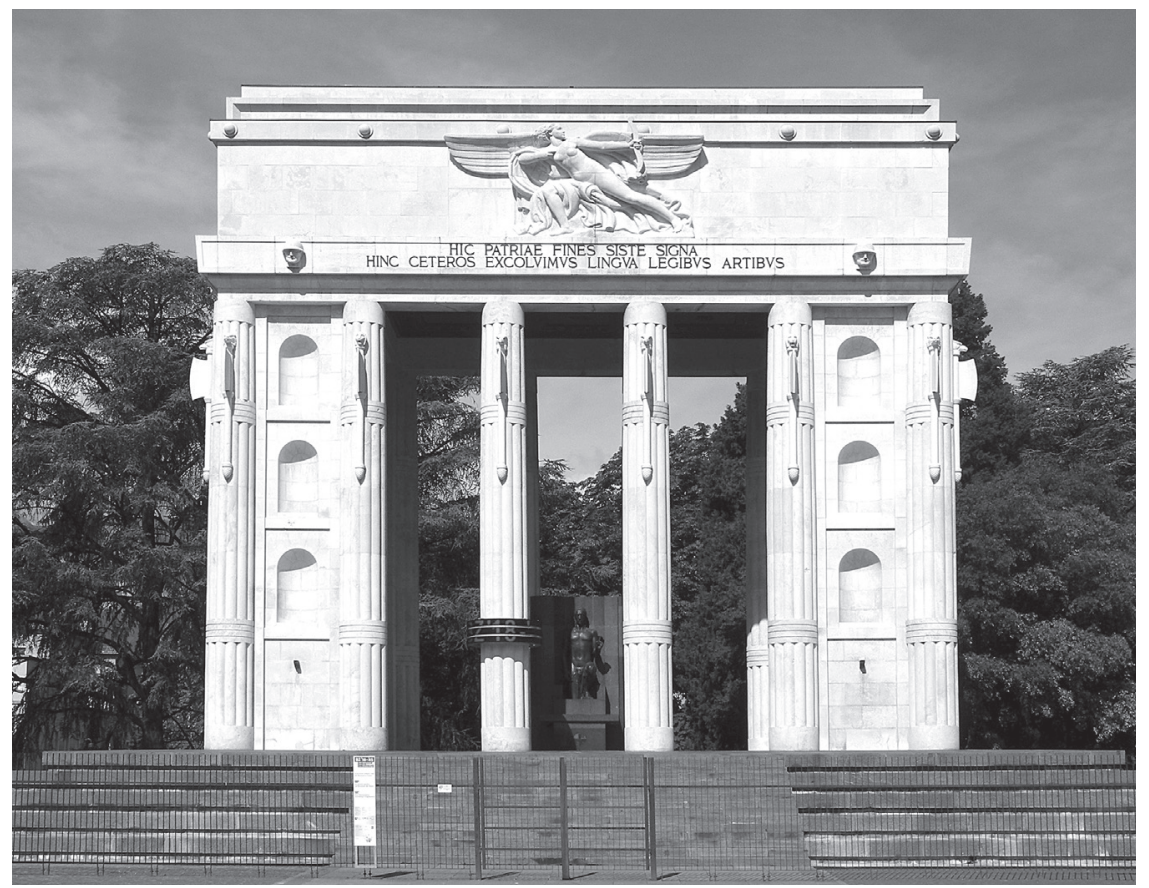

Figure 1: The Victory Monument in Bolzano/Bozen, Italy.

Source: Photo ㄷ Gruppe Gut.

Commissioned by Benito Mussolini, the monument was built in the 1920s to celebrate Italy's victory over Austria-Hungary in World War I. For the German-speaking population of South Tyrol, which had been a territory of the Habsburg Empire until the end of the War when it became part of Italy, it was a concrete reminder of the Fascists' domination and oppression of the region. Almost a century later, the Victory Monument still stands in its original location

1 HIC PATRIAE FINES SISTE SIGNA / HINC CETEROS EXCOLUIMUS LINGUA LEGIBUS ARTIBUS. 
and continues to spark regular debates about the place of a fascist monument in today's world. Most recently, a major intervention has attempted to transform the divisive nature of the monument; since 2014, a permanent exhibition inside the monument challenges its negative symbolic power by historicizing and (re)contextualizing it. Thus, the once-divisive monument is set to become an instrument for bridging South Tyrol's divergent memory cultures, improving relations between South Tyrol's different language communities, and fostering a peaceful future.

This article explores how the Victory Monument and its symbolic power has been reshaped by this new permanent exhibition. After providing a brief theoretical overview of the role of cultural heritage, and monuments in particular, in divided societies, we introduce our case study with an overview of the history of South Tyrol and the Victory Monument. We then analyze the multitude of discourses and ceremonies related to the monument over the years, from its erection in 1928 to the opening of the permanent exhibition inside it in 2014.

Drawing on interviews with the exhibition curators, texts from the exhibition catalogue, statements by politicians and public intellectuals, and media discourses, as well as the body of scholarship on Fascist monuments in South Tyrol and beyond, we explore to what extent the original monument preserved the experiences and memories of the traumatic events of the past that have affected group relations in South Tyrol over the years. This paper also seeks to explain how well the permanent exhibition has succeeded in reframing the symbolic and political discourse surrounding the Victory Monument. Finally, we briefly consider whether the multiple narratives promoted by the museum sufficiently include alternative memory cultures, such as those of the increasing number of migrants settling in the region.

The controversies surrounding the Victory Monument are far from unique. From debates about the contemporary meaning of the heritage of national socialism, fascism, socialism and colonial rule ${ }^{2}$ to violent ethno-religious conflict

2 Henrika Kuklick, "Contested Monuments: The Politics of Archaeology in Southern Africa," in Colonial Situations: Essays on the Contextualization of Ethnographic Knowledge, ed. George W. Stocking, Jr. (Madison: University of Wisconsin Press, 1991); Sharon Macdonald, "Undesirable Heritage: Fascist Material Culture and Historical Consciousness in Nuremberg," International Journal of Heritage Studies 12, No. 1 (2006): 9-28, doi: 10.1080/13527250500384464; Sharon Macdonald, "Reassembling Nuremberg, Reassembling Heritage," Journal of Cultural Economy 2, No. 1-2 (2009):117-134, doi: 10.1080/17530350903064121; Klaus Neumann, Shifting Memories: The Nazi Past in the New Germany (Ann Arbor: The University of Michigan Press, 2000); D. J. Smith, "Woe from Stones: Commemoration, Identity Politics and Estonia's 'War of Monuments," 
in the Balkans, Afghanistan, Israel and Palestine, and Africa, ${ }^{3}$ heritage is contested worldwide. Scholarship in the field of ethnic politics and the literature on historical legacies within it tend to focus on tensions and conflicts and thus overrepresent the negative face of ethnic diversity. ${ }^{4}$ However, peaceful and cooperative ethnic relations are actually more common than violent ones. ${ }^{5}$ Thus, this paper departs from a negative presentation of ethnic diversity; rather than highlighting conflict, we focus on the most recent developments concerning the Victory Monument and explore approaches which seek to make heritage, and by extension society as a whole, more inclusive and pluralistic.

Using the monument as a case study, this paper investigates the role of monuments in managing and negotiating interpretations of the past in culturally heterogeneous societies. It explores approaches that seek to overcome the exclusionary potential of heritage, reframing it in more inclusive and pluralistic terms. It provides an in-depth analysis of a dialogical, pluralistic approach to heritage that allows divergent, even contrary, interpretations of the past to coexist. In that way, this paper sheds light on how monuments (re)construct and contest memory and history and provides insight into constructive ways of engaging with controversial heritages in multiethnic societies.

Journal of Baltic Studies 39, No. 4 (2008): 419-430, doi: 10.1080/01629770802461191; Blair Ruble, John Czaplicka and Nida Gelazis, Cities after the Fall of Communism: Reshaping Cultural Landscapes and European Identity (Baltimore, MD: Johns Hopkins University Press, 2009); Dacia Viejo-Rose, Reconstructing Spain: Cultural Heritage and Memory after Civil War (Brighton: Sussex Academic Press, 2011); Paolo Pantaleo, "Lettonia: chi vuole rimuovere il monument alla vittoria?" East Journal, October 30, 2013, http://www.eastjournal.net/archives/35845.

3 Robert Bevan, The Destruction of Memory: Architecture at War (Chicago, IL: University of Chicago, 2006); John Chapman, "Destruction of a Common Heritage: The Archaeology of War in Croatia, Bosnia and Hercegovina," Antiquity 68 (1994):120-126, doi: 10.1017/ S0003598X00046251; Gregory Ashworth and Bart J. M. van der Aa, "Bamyan: Whose Heritage Was It and What Should We Do About It?" Current Issues in Tourism 5, No. 5 (2002): 447-457, doi: 10.1080/13683500208667934; Nadia Abu El-Haj, "Translating Truths: Nationalism, Archaeological Practice and the Remaking of Past and Present in Contemporary Jerusalem," American Ethnologist 25, No. 2 (1998): 166-188, doi: 10.1525/ae.1998.25.2.166; Paul Basu, "Confronting the Past? Negotiating a Heritage of Conflict in Sierra Leone," Journal of Material Culture 13, No. 2 (2008): 233-247; Martin Hall, Archaeology and the Modern World: Colonial Transcripts in South Africa and the Chesapeake (New York, NY: Routledge, 2000).

4 Smith, "Woe from Stones"; Marko Lehti, Matti Jutila and Markku Jokisipilä, "Never Ending Second World War: Public Performances of National Dignity and Drama of the Bronze Soldier," Journal of Baltic Studies 39, No. 4 (2008): 393-418, doi: 10.1080/01629770802461175.

5 James Fearon and David Laitin, "Explaining Interethnic Cooperation," American Political Science Review 90, No. 4 (1996): 715-735, doi: 10.2307/2945838. 


\section{Understanding Cultural Artifacts: Identities, Memories and Conflicts}

Heritage is not simply "what is left from the past." It is a powerful instrument employed to construct and strengthen a nation's common (hi)story, identity and continuity. As "imagined communities," 6 nations are made tangible by embedding them in a physical, lived-in landscape - "a special place of belonging," 7 which establishes the boundaries necessary for people to orient themselves, to develop their self-understanding as a nation, and to identify with heritage. Heritage artifacts "act as cues for expressing identity," legitimize national ideology, and cement the hegemony of elites. ${ }^{9}$ Monuments are "flashpoint[s] of struggles over history, politics and identity" 10 and "vessels of [collective] memory." 11 In monuments, "time collapses into space" and assumes material form. ${ }^{12}$ As expressions of collective memories, monuments are not simply historical artifacts that represent the past; rather they are lieux de mémoire and as such, phenomena that project themselves into the present and future. ${ }^{13}$ This process is dialogical; monuments and their representations of the past affect our understanding of the present. At the same time, the forms in which monuments crystallize the past are not immutable. Their meaning is interpreted in the present, influenced by ever-changing conditions.

Monuments' intimate relationships with collective identities and memories turn them into potential sources of division and conflict. Indeed, the process by which monuments are selected and turned into part of the national fabric is neither cohesive nor unproblematic. While a monument can provide a shared narrative and a sense of belonging to those who see themselves represented in it, "those who cannot see themselves reflected in its mirror cannot properly

\footnotetext{
${ }^{6}$ Benedict Anderson, Imagined Communities (London and New York: Verso, 1991).

7 Ross Poole, Nation and Identity (London and New York: Routledge, 1999), 127.

8 Sarah Jane Meharg, "Identicide and Terrains of Opportunity: The Problem with Post-Conflict Reconstruction" (Paper presented at the Annual Conference of the Regional Peace Studies Consortium, Syracuse, 13 November 2004), 7.

9 Abu El-Haj, "Translating Truths."

10 Bill Niven, "War Memorials at the Intersection of Politics, Culture and Memory," Journal of War and Culture Studies 1, No. 1 (2008): 45, doi: 10.1386/jwcs.1.1.39_0.

${ }_{11}$ Meharg, "Identicide and Terrains of Opportunity," 6.

12 James E. Young, The Texture of Memory (New Haven and London: Yale University Press, 1993), 15.

13 Pierre Nora, "Between Memory and History: Les Lieux de Memoire," Representations 26 (1989): 8-9, doi: $10.2307 / 2928520$.
} 
"belong." 14 In the words of Tunbridge and Ashworth, "all heritage is someone's heritage and therefore logically not someone else's: the original meaning of an inheritance implies the existence of disinheritance and by extension any creation of heritage from the past disinherits someone completely or partially, actively or potentially." 15 As those who are excluded, disinherited and marginalized begin to challenge, contest and rewrite the dominant narrative, monuments become sites of contestation between divergent collective identities and memories.

How to deal with sites of "dissonant heritage" is not a straightforward question. ${ }^{16}$ Their removal is often proposed as a solution. However, the destruction of places and landmarks may destabilize identities and provoke social disorder, and it might be considered a form of "identicide." 17 Another option is the modification of the meaning of a monument by erasure of its most problematic and controversial aspects. However, the result of both these options is a "community of forgetting" that is, as Booth argues, a world without a common life or shared identity, and a place without morality. ${ }^{18}$ Such revisionism is based, says Habermas, "on the assumption that one can turn the spotlights of arbitrarily reconstructed past histories on the present and from the options illuminated select a particularly appropriate picture of history." 19 Instead, Habermas suggests retaining reminders of the negative elements of the past in order to bind society together more tightly.

Rather than simply removing contested interpretations or memories of the past, it is necessary to recognize the memories of different groups "so that each may know and respect the other's version of the past, thereby understanding better what divides and unites" them. ${ }^{20}$ Such a multi-voice approach to heritage encourages reflection on the past as process, ${ }^{21}$ and creates "a state of 'negotiated

${ }^{14}$ Stuart Hall, "Whose Heritage? Un-settling 'The Heritage,' Re-imagining the Post-Nation," in The Politics of Heritage: The Legacies of 'Race,' ed. Jo Littler and Roshi Naidoo (London: Routledge, 2005), 24.

${ }^{15}$ John E. Tunbridge and Gregory Ashworth, Dissonant Heritage: The Management of the Past as a Resource in Conflict (New York: John Wiley \& Sons, 1996), 21.

16 Ibid.

${ }^{17}$ Meharg, "Identicide and Terrains of Opportunity."

${ }^{18}$ James W. Booth, "Communities of Memory," in Canadian Political Philosophy, ed. Ronald Beiner and Wayne Norman (Ontario: Oxford University Press, 2001), 277.

19 Jürgen Habermas, The New Conservatism: Cultural Criticism and the Historian's Debate (Cambridge, MA: MIT Press, 1989), 214.

${ }^{20}$ Gillis, quoted in Aletta J. Norval, "Memory, Identity and the (Im)possibility of Reconciliation: The Work of the Truth and Reconciliation Commission in South Africa," Constellations 5, No. 2 (1998): 260, doi: 10.1111/1467-8675.00091.

${ }^{21}$ Macdonald, "Reassembling Nuremberg." 
memory' based on mutual critical engagement with the past and greater tolerance of different viewpoints."22

Heritage sites thus carry within them the dual potential to bring communities together or pull them apart. They embody memories that can unite as well as divide. They shape interpretations and imaginations of the past, present and future that can be either inclusive or exclusive, and they act as cues for articulating multiple national identities. The recent interventions and reinterpretations of the Victory Monument in South Tyrol presented below are an example of attempts to reframe Italy's cultural heritage by approaching the divisive legacies of the past critically and reflexively, in order to make the heritage accessible to everyone regardless of ethnic and linguistic community boundaries.

\section{The Historical Context of South Tyrol}

The Autonomous Province of Bolzano/Bozen, also known as South Tyrol, is located in northern Italy, on the Austrian and Swiss borders. Its population of approximately 516,000 is composed of 70\% German-speakers, 26\% Italian-speakers and $4.5 \%$ Ladin-speakers. The large percentage of German-speakers living in South Tyrol is the result of a shift in the borders after the First World War, when South Tyrol, until then part of the Habsburg Empire, became part of Italy. When Fascist dictator Benito Mussolini came to power some years later in 1923, he started a program for the Italianization of South Tyrol. This included, for instance, a prohibition on the use of the German language, the closure of German-language schools and newspapers, the Italianization of names, and the replacement of local administrators with personnel from other parts of Italy. Newly built industry attracted Italian migrant workers and led to an increase of the Italian population from 7,000 people in 1910 to more than 100,000 in 1943. In 1939, Hitler and Mussolini signed the South Tyrol Option Agreement under which South Tyroleans had to decide whether to retain their right to speak German but emigrate to the Third Reich, or to stay and accept the Fascists'

${ }^{22}$ Müller, quoted in Smith, "Woe from Stones"; see also Basu, "Confronting the Past"; Keld Buciek and Kristine Juul, “'We Are Here, Yet We Are Not Here': The Heritage of Excluded Groups," in Ashgate Research Companion to Heritage and Identity, ed. Graham Brian and Peter Howard (Abingdon: Ashgate Publishing Group, 2008); Gabi Dolff-Bonekämper, "Cultural Heritage and Conflict: The View from Europe," Museum International 62, No. 1-2 (2010): 14-19, doi: 10.1111/ j.1468-0033.2010.01713.x; Lynn Meskell, "Negative Heritage and Past Mastering in Archaeology," Anthropological Quarterly 75, No. 3 (2011): 557-574; Brian S. Osborne, Landscapes, Memory, Monuments, and Commemoration: Putting Identity in Its Place (2001), http://canada.metropolis.net /events/ethnocultural/publications/putinden.pdf; Tunbridge and Ashworth, Dissonant Heritage. 
Italianization program. Eighty-six percent of South Tyroleans officially opted for leaving, although only about thirty-seven percent actually did so. ${ }^{23}$

After World War II, the foreign ministers of Italy and Austria, Alcide De Gasperi and Karl Gruber, signed an agreement that assured South Tyrol's German-speaking inhabitants they would not face discrimination and provided for their political autonomy. However, the Italian state implemented the agreement poorly and ethnic tensions simmered from the late 1950s to the 1970s. Separatist activists targeted symbols of the Italian state, such as Fascist monuments, police stations, state-funded housing projects, and power plants. The tense situation improved in 1972 when the Italian government enacted the Second Statute of Autonomy, which introduced additional measures to protect the German and Ladin minority populations in South Tyrol and led to a settlement of the conflict and the reduction of separatist tendencies.

Through the Second Statute of Autonomy, the German-speaking population in South Tyrol enjoys one of the world's most advanced systems of minority protection. It is often described as a model for resolving ethnic tensions and protecting national minorities in various contexts from Bosnia-Herzegovina to Tibet and more recently in Ukraine. ${ }^{24}$ It is a "complex power sharing system," 25 which combines extensive territorial autonomy with various consociational elements. These include proportional representation of the linguistic groups in the provincial legislature and executive governmental bodies, the distribution of public employment and public resources among the linguistic groups in proportion to their numerical strength, mandatory bilingualism on public signage and for public officials, and mother-tongue education, implemented in three separate school systems.

Critics of the autonomy system point out, however, that because of rigid separation between the linguistic groups, it has crystallized divisions between

${ }^{23}$ Georg Grote, Ich bin a Südtiroler: Kollektive Identität zwischen Nation und Region im 20. Jahrhundert (Bozen: Athesia, 2009), 138. For further historical accounts of South Tyrol see also: Rolf Steininger, South Tyrol. A Minority Conflict of the Twentieth Century (New Brunswick, NJ: Transaction Publishers, 2003); Leopold Steurer, Südtirol zwischen Rom und Berlin. 1919-1939 (Wien: Europa Verlag, 1980); Michael Gehler, ed., Akten zur Südtirol - Politik 1945-1958. 1945-1947 Gescheiterte Selbstbestimmung (Wien: Studienverlag, 2011).

${ }^{24}$ Roland Benedikter, "Overcoming Ethnic Division in Iraq: A Practical Model from Europe," The National Interest, February 11, 2004; Roland Benedikter, "East Ukraine's Four Perspectives: A Solution According to the South Tyrol Model," Ethnopolitics Papers 37 (2015): 1.

25 Stefan Wolff, "Complex Power Sharing as Conflict Resolution: South Tyrol in Comparative Perspective," in Tolerance through Law. Self-Governance and Group Rights in South Tyrol, eds. Jens Woelk, Francesco Palermo and Joseph Marko (Leiden and Boston: Martinus Nijhoff Publishers, 2008). 
institutions in many aspects of social and political life. ${ }^{26}$ Each language group has created its own separate structures, such as trade unions, political parties, associations and mass media, thereby limiting social contact between the groups. ${ }^{27}$ Moreover, some scholars highlight that the groups enjoying autonomy in South Tyrol no longer match the changing demography of the territory. The Statute of Autonomy does not take into account the increasing number of bi- or multi-lingually-raised people (an estimated 25,000 to 35,000 people); ${ }^{28}$ nor the growing number of migrants, who in 2016 constituted $8.9 \%$ of the province's population. ${ }^{29}$ Over the past decade, however, there have been improvements in terms of increased trust, interaction and cooperation among South Tyrol's elites and development of interethnic civil society initiatives. ${ }^{30}$

\section{The Victory Monument}

Designed by architect Marcello Piacentini and inaugurated by King Vittorio Emanuele III in 1928, the Victory Monument was erected as symbol of the victory of Italian troops over Austria-Hungary in World War I. It was an "architectural symbol of the fascist spirit," as Piacentini himself stated. ${ }^{31}$ By its location at the site of an earlier Austrian war memorial and the inscriptions on both its interior and exterior, "the entire symbolism of the monument expressed the conquest of South Tyrol and its economic, infrastructural and cultural penetration" by Italy. ${ }^{32}$

${ }^{26}$ Joseph Marko, “Is There a South Tyrolean 'Model' of Conflict Resolution to be Exported?” in Tolerance through Law. Self-Governance and Group Rights in South Tyrol, eds. Jens Woelk, Francesco Palermo and Joseph Marko (Leiden and Boston: Martinus Nijhoff Publishers, 2008), 386; Andrea Carlà, "Living Apart in the Same Room: Analysis of the Management of Linguistic Diversity in Bolzano," Ethnopolitics 6, No. 2 (2007): 285-313, doi: 10.1080/17449050701345041.

27 Günther Pallaver, "South Tyrol's Consociational Democracy: Between Political Claim and Social Reality," in Tolerance through Law. Self-Governance and Group Rights in South Tyrol, eds. Jens Woelk, Francesco Palermo and Joseph Marko (Leiden and Boston: Martinus Nijhoff Publishers, 2008), 311-312.

${ }^{28}$ Alessandro Pallaoro and Micaela Colletti, “'Nuove' minoranze in Alto Adige/Südtirol: impatto sugli strumenti a tutela delle 'vecchie' minoranze," in Politiche Migratorie e Autonomie Territoriali. Nuove Minoranze, Identità e Cittadinanza, eds. Roberta Medda-Windischer and Andrea Carlà (Bolzano: Eurac Research, 2013), 119.

29 Centro Studi e Ricerche IDOS, Dossier Statistico Immigrazione 2017 (Roma: IDOS Edizioni, 2017), 440.

30 Günther Pallaver, "South Tyrol's Changing Political System: From Dissociative on the Road to Associative Conflict Resolution," Nationalities Papers 42, No. 3 (2014): 376-398, doi: 10.1080/00905992.2013.856393.

31 Stadt Bozen, BZ '18-'45: One Monument. One City. Two Dictatorships (Vienna-Bolzano: Folio, 2016), 125.

32 Soragni quoted Ibid., 25. 
As explained by historian Hannes Obermair, the construction of the Monument was part of a movement initiated by the Fascist regime that was aimed at destroying Austro-Tyrolean memories and Italianizing South Tyrol and its urban landscape. ${ }^{33}$ The monument employed a multilayered symbolism, expressed through its architecture, its Latin inscriptions, its sculptures by the Italian patriot Cesare Battisti, and its statue of Victory Sagittarius, a female archer shooting northward toward Austria. It was "the bearer of various messages: the commemoration of the Italian martyrs in the First World War; the exaltation of Italian victory and the conquest of the 'natural borders'; the supposed superiority of the Latin civilization; the triumph of Fascism." 34 To the German-speaking population of South Tyrol, however, the monument soon became a symbol of oppression and discrimination under Fascism and, after the fall of Mussolini, under the Italian state more generally. ${ }^{35}$ It thus embodied two highly dissonant interpretations of the past, representing for the German-speaking population "the Fascist conquest through architecture" and the "symbolic colonization" of South Tyrol by Italy on the one hand, and, on the other hand, for the Italian-speaking population, a symbol of Italian history and identity. ${ }^{36}$

Considering this historical and socio-political background, it is not surprising that the Victory Monument has been contentious from the beginning and has been used to assert group identities and stake out political claims. ${ }^{37}$ As the "tip of a larger cleavage," 38 the monument became "the focal point of battles over politics, culture, and regional identity." ${ }^{9}$ For instance, in 1943, soon after the fall of Mussolini, a group of Nazi sympathizers damaged the monument. During the political tensions of the 1960s and 1970s, the monument became a key site for protest and displays of power. An explosion in 1978 nearly caused the monument to collapse; a year later, a political activist carried out a hunger strike in front of the monument. As a result of these actions, the monument was closed off

${ }^{33}$ Hannes Obermair, "Monument and City - A Tormented Relationship," in Ibid., 123.

${ }^{34}$ Ibid., 135.

35 Johanna Mitterhofer, "Competing Narratives on the Future of Contested Heritage: A Case Study of Fascist Monuments in Contemporary South Tyrol, Italy," Heritage \& Society 6, No. 1 (2013): 46-61, doi: 10.1179/2159032X13Z.0000000006.

${ }^{36}$ Georg Mair, “Monumente, die uns prägen," ff 06 (2011).

37 Hannes Obermair and Sabrina Michielli, "Erinnerungskulturen des 20. Jahrhunderts im Vergleich / Culture della memoria del Novecento a confronto," Quaderni di storia cittadina / Hefte zur Bozner Stadtgeschichte 7 (2014).

38 Alessandro Leogrande, "La redenzione elettronica di un relitto fascista," pagina99 (December 6, 2014), 29.

${ }^{39}$ Jeffrey Schnapp, “About a Monument and a Ring,” July 23, 2014, http://jeffreyschnapp.com/tag /monuments/. 
with a fence for security reasons. Meanwhile, it became a place for commemorative ceremonies by Italian-speaking nationalists (and celebrations of the victories of the Italian national football team by sports fans). Until 1997 it was the locus of military ceremonies.

\section{What Next for the Monument?}

"Monuments don't hurt," Giorgio Holzmann, a South Tyrolean right-wing politician, once stated. ${ }^{40}$ In contrast, historian John Foot writes that the monument was created "to sow discord" and, as historian Hannes Obermair states, "it managed to do so perfectly." 41 As highlighted above, the victory monument "hurt" when it was built, and it continued to hurt long after: "Some monuments slip into oblivion. Others, however, remain at the center of disputes: they become the focal point of issues related to the political present and future, to the identity and culture of a society." 42 The Victory Monument was one such focal point. For Bolzano/Bozen and South Tyrol it is a "boulder that history has forgotten to remove." 43

Discussions about the monument's future have thus been intense and highly politicized. ${ }^{44}$ While Italian right-wing parties called for the preservation of the monument, which they considered part of the Italian cultural heritage, rightwing parties representing German-speaking South Tyrol called for its demolition. More moderate proposals included the removal of fascist symbols to weaken the divisive force of the monument, ${ }^{45}$ a name change from Victory Monument to Peace Monument in order to transform it into a symbol of peace between the Italian and German communities, ${ }^{46}$ and the addition of information panels to contextualize the monument historically.

40 Quoted in Marco Angelucci, "Sfiducia a Bondi, si tratta L'SVP: spostare anche l'Alpino," Corriere dell'Alto Adige, January 26, 2011, https://www.pressreader.com/italy/corriere-dellalto-adige /20110126/281483567842299.

${ }^{41}$ Interview with Hannes Obermair, March 16, 2017.

42 Stadt Bozen, $B Z$ '18-'45, 138.

43 Obermair, "Monument and City," 122.

${ }^{44}$ For an in-depth discussion on the divergent public discourses about the Victory Monument, see Mitterhofer, "Competing Narratives."

45 Along those lines, as early as 1979 the left-wing politician and activist Alexander Langer proposed in the Provincial Parliament - in vain - an intervention in order to transform the monument's meaning and improve interethnic relations, which at the time were very tense.

${ }^{46}$ In 2002 the City Council of Bolzano decided to change the name of the homonymous square adjacent to the monument from Piazza della Vittoria (Victory Square) to Piazza della Pace (Peace 
In 2011, after years of debate, and following an agreement between three key actors (the Italian state, the South Tyrolean provincial government and the municipality of Bolzano/Bozen), a commission of historians and art historians was tasked to elaborate a concept for the historical contextualization of the Victory Monument. ${ }^{47} \mathrm{~A}$ year later, the three governments agreed to implement the concept elaborated by the Commission - a permanent exhibition about the Victory Monument and South Tyrol's more recent history. They jointly funded the project.

According to Hannes Obermair, a historian and one of the members of the Commission, a conjunction of various political circumstances opened a window of opportunity that led to this decision. Italy's then-Minister of Culture, Sandro Bondi, delegated making the decision about the future of the Fascist monument from the Italian state to the province of Bolzano. A new president of the province was elected after 25 years of government by Luis Durnwalder (1989-2014). The government of Silvio Berlusconi ended. Furthermore, a new generation of South Tyrolean Italian-speaking and German-speaking historians, who were working on the histories and memories of all South Tyrolean language communities, provided a body of scholarship necessary for the proper historicization of the monument. ${ }^{48}$

The permanent exhibition inside the monument was meant to open up a public dialogue about the differing interpretations of the monument's role in South Tyrol's heritage by critically reflecting the political-social context in which it was created and the role it has played in South Tyrol since its conception. ${ }^{49}$ Composed of members from the two main language groups, as well as representatives from municipalities, the province, and the state, ${ }^{50}$ the Historical

Square). This decision was overturned by a referendum in which $62 \%$ of the inhabitants of Bolzano/Bozen (who are prevalently Italian speakers) voted for maintaining the old name.

47 In connection with restoration works on the monument in 1973, a historical commission was given the task of finding solutions for the proper contextualization of the Victory Monument. Due to the political climate of the time, this first attempt was not successful. See Stadt Bozen, BZ '18-'45, 25.

${ }^{48}$ Leogrande, "La redenzione elettronica," 29. These historians also launched a petition to preserve and yet also historicize the Fascist monuments in South Tyrol. See Davide Pasquali, "L'appello degli storici italiani e tedeschi 'Il passato va spiegato senza rimozioni'," Alto Adige, February 5, 2011.

49 Johanna Mitterhofer, "Beyond the Nation: Making Heritage Inclusive," in Heritage at the Interface: Interpretation and Identity, eds. G. Hooper and P. A. Shackel (Gainesville, FL: University Press of Florida, 2017), 136-147.

50 The Historical Commission's members were Ugo Soragni (representing the Italian state), Christine Roilo and Andrea di Michele (representing the Province of South Tyrol), Hannes Obermair, and Silvia Spada (representing the municipality of Bozen/Bolzano). 
Commission underscored right from the beginning the dialogical nature of the new approach to South Tyrol's heritage. ${ }^{51}$

\section{BZ '18-'45: One Monument. One Town. Two Dictatorships}

Nevertheless, it should come as no surprise that the decision to open an exhibition in the Victory Monument caused a new wave of public debate. While some left-wing parties celebrated the exhibition as a breakthrough, adherents of German-speaking right-wing parties considered it a concession made to fascism. The Italian right considered it an illegitimate attempt to modify a historical monument. ${ }^{52}$

Given expectations of the politicization of the project, a non-interference clause in its statute shielded the work of the Historical Commission from political influence. As explained by the president of the Commission, Ugo Soragni, "we needed to work without direct political interference." 53 According to two members of the Commission, Hannes Obermair and Silvia Spada, politicians respected this clause:

We were only given the instruction to put together an exhibition in the spaces below the monument that would tell its history and contextualize it. We knew that if politics had entered our discussions, or if all our plans and texts for the exhibition would have needed to be approved by the Provincial Government, nothing would ever have come out of it. Our work would have been impossible. ${ }^{54}$

According to Spada, the primary task of the Commission was to open up the monument - until then closed to the public - and tell its history and that of the region with dates and facts. The hope was to rid it of its "mysterious aura" and the many half-truths and misinterpretations associated with it. "You may like or dislike the monument, but now you can at least enter and judge for yourself! We wanted to make it possible for people to form their own judgment about the past, without being influenced ideologically." 55

\footnotetext{
51 Obermair and Michielli, "Erinnerungskulturen."

52 See the collection of related articles in Stadt Bozen, Pressespiegel Siegesdenkmal (2012), http:// www.gemeinde.bozen.it/cultura_context.jsp?ID_LINK=3921\&page $=3 \&$ area $=48 \& i d$ _context $=19564$.

53 Quoted in Francesca Gonzato, "Nuovo Monumento Processione senza fine," Alto Adige, July 23, 2014.

${ }^{54}$ Interview with Silvia Spada, March 14, 2017.

55 Ibid.
} 
By being opened to the public, explored, and studied, the monument has lost its intangible, mythic nature. Providing information about its history weakens its divisive potential. The Commision was aware that no date or fact is ever completely objective and that conflicting historical narratives were unavoidable. Therefore, rather than seeking to please everyone by selecting only uncontentious, consensual aspects of the monument's and the region's history or by harmonizing two contrasting sets of memories, the Commission took a different approach. "It would have been impossible to please everyone. Instead, we realized that we had to displease everyone." ${ }^{6}$ Only by portraying history "as grey, rather than black or white, ${ }^{\prime 57}$ could they avoid their work causing further divisions amongst the population, which, according to Spada, was the biggest challenge of the project. One principle guiding the work of the commission was not to "censor anything." Thus, the exhibition highlights not only the process of Italianization in South Tyrol, but also the benefits of the public infrastructure constructed during the Fascist regime. ${ }^{58}$ The commission embraced awareness of the multifaceted aspects of history in order to transform the monument into a place for critical reflection.

The new, permanent exhibition in the subterranean spaces of the Victory Monument opened in 2014. Entitled BZ '18-'45: One Monument. One Town. Two Dictatorships, it explores the monument's history against the backdrop of the events of 1918-1945, focusing on the period of fascism and national socialism in South Tyrol. ${ }^{59}$ Visitors can explore the role and meaning of monuments in general and reflect critically on the past and future of the monument. In the entrance room, audiovisual installation projects overlap Fascist and Nazi slogans and anthems, rendering them indistinguishable, yet evanescent. ${ }^{60}$ In the monument's crypt, quotations from Hannah Arendt, Bertolt Brecht and Thomas Paine are projected on the walls, warning of the dangers of dictatorships and the importance of democracy. They "neutralize" the original frescoes by painter Guido Cadorin and the inscriptions from classical Roman texts praising fame, virtue,

\footnotetext{
${ }^{56}$ Interview with Silvia Spada, March 14, 2017.

57 Interview with Hannes Obermair, March 16, 2017.

58 Ugo Soragni, quoted in Gonzato, "Nuovo Monumento."

${ }^{59}$ Konzept zur Gestaltung der Dokumentations-Ausstellung im Siegesdenkmal Bozen (2014), www .siegesdenkmal.com/fileadmin/user_upload/pdfs/GGG_MaV_Konzept-DE.pdf.

${ }^{60}$ Stadt Bozen, BZ '18-'45, 16; See also Gruppe Gut, "Progetto di allestimento per un percorso espositivo nel monumento alla vittoria di Bolzano," July 21, 2014, http:/ /www.monumentoallavittoria .com/fileadmin/user_upload/pdfs/GGG_MaV_Concetto_ITA.2.pdf.
} 
and the honor of sacrifice for one's country. ${ }^{61}$ The main exhibition is organized into three "paths." The first path focuses on the region's macro-history from 1918 to 1945 , while the second presents the micro-history of the monument. The third path addresses four different, yet interrelated questions: What is a monument? What elements compose the Victory Monument? Who was Marcello Piacentini? What do citizens demand of monuments today?62

In a context where language remains a contested issue despite decades of peaceful cohabitation between different communities and official bilingualism, the use of language in the exhibition texts is significant. On signs, English appears first, followed by Italian and German. The Commission chose to use English as the first language of the exhibition to avoid the primacy of one local language over the other. ${ }^{63}$ This peculiar decision was an attempt to keep the historical contextualization and explanation of the monument as neutral as possible, and to protect it from possible controversy. It should be noted that the Commission did not include Ladin, the third official language of South Tyrol, on the signs in the exhibition. ${ }^{64}$

The exterior of the monument was left untouched, apart from the addition of a LED ring on one of the columns. This subtle, yet highly visible intervention, which breaks the monumental nature of the façade, is described as "neutralizing" and "contradicting" the ideology of the monument without damaging or erasing it. The ring is "highlighting the critical engagement with Fascist ideology," 65 as a "symbol of discontinuity and disruption" 66 and a "nose ring for Fascist rhetoric." 67 As explained by Jeffrey Schnapp, scientific advisor to the Commission, the ring aims "to unbalance the façade with its neoclassical symmetries - not to mention, the ideology embedded within those neoclassical symmetries - in the name of post-fascist-era balance." It "marks the difference between the totalitarian then [...]" and "a now characterized by cultural pluralism and tolerance." Thus, "by unbalancing, the ring rebalances; by defamiliarizing, it refamiliarizes." 68 As the only visible external element that locates the monument squarely in the pres-

\footnotetext{
${ }^{61}$ The quotations from Hannah Arendt, Bertolt Brecht and Thomas Paine are, respectively, "Nobody has the right to obey," "Unhappy the land that is in need of heroes," and "The duty of a patriot is to protect his country from its government." Stadt Bozen, BZ '18-'45, 14.

62 Gruppe Gut, "Progetto di allestimento," 10.

63 Interview with Hannes Obermair, March 16, 2017.

${ }^{64}$ Information material about the exhibition was later translated into Ladin.

65 Stadt Bozen, BZ '18-'45, 16, 29.

${ }^{66}$ Interview with Silvia Spada, March 14, 2017.

67 Stadt Bozen, BZ '18-'45, 29.

68 Schnapp, "About a Monument."
} 
ent, the ring distances the monument from the past without erasing its history. According to Andrea di Michele, one of the members of the Commission, the idea of the ring was to signal, even to those who do not enter the exhibition, "that something has happened" with the monument and that South Tyrolean society and institutions have launched a process of reflection about it. ${ }^{69}$ As explained by Demetz and Prugger of Gruppe Gut, the design firm that oversaw preparation of the exhibition, the "irony and lightness" of the LED ring were more appropriate and "less traumatic" than adding new, heavy architectural elements to represent the breach with the past. ${ }^{70}$

The opening of the permanent exhibition and the addition of the LED ring have transformed the Victory Monument into a "counter monument" in order to "register protest or disagreement with an untenable prime object and to set a process of reflection in motion." 71 BZ '18-'45: One Monument. One Town. Two Dictatorships is "an exemplary effort to reintegrate a controversial monument," says Jeffrey Schnapp. ${ }^{72}$ It has become "a radically different monument, a monument 2.0."73 If previously the monument had been used (and abused) primarily by right-wing extremists who used its symbolic power to divide and sow discontent, the controversies surrounding the monument have largely disappeared since the changes were made. ${ }^{74}$ Nevertheless, the monument continues to be a disruptive element within the city and the larger region - "an open wound"75 - and as such, it still commands attention. In contrast to the past, when the visitor's attention was unable to pass through the stones of the façade and citizens were unable to interact with the "intimidating" monument, visitors can now enter and explore it from both outside and inside. "It is now possible to reclaim the space, interact with it and use it." ${ }^{76}$ Soragni, the president of the Commission, points out that the monument remains an object with several meanings, but that the various meanings are now explained. ${ }^{77}$

${ }^{69}$ Quoted in Gabriele Di Luca, "Il timbro di Sgarbi," Salto.bz, July 23, 2014.

${ }^{70}$ Quoted in Paolo Campostrini, "Gli inventori dell'anello «Serviva un po' di ironia»," Alto Adige, July 31, 2014. Besides philosophical considerations, economic factors also played a role; the ring was significantly cheaper than other proposals. See Gruppe Gut, "Progetto di allestimento," 11.

${ }^{71}$ Sergiusz Michalski quoted in Michael Landzelius, "Commemorative Dis(re)membering: Erasing Heritage, Spatializing Disinheritance?” Environment and Planning D: Society and Space 21, No. 2 (2003), 212.

72 Schnapp, "About a Monument."

${ }^{73}$ Interview with Hannes Obermair, March 16, 2017.

${ }^{74}$ Ibid.; Interview with Silvia Spada, March 14, 2017.

75 Interview with Hannes Obermair, March 16, 2017.

${ }^{76}$ Ibid.

77 Quoted in Gonzato, “Nuovo Monumento." 
The exhibition has transformed the monument from an artifact of a violent history into an open space for critical reflection that belongs to everyone and where anyone can "discuss, ask questions and look for possible answers." 78 Through the democratization of its space, the monument has become a place where knowledge is presented, but also contested and remade. Instead of negating or obliterating the fascist nature of the monument, the monument's troubled past is used as a resource ${ }^{79}$ to explain the ideologies of dictatorships and the divisive power of monuments. As explained by Obermair, "from a monument conceived in the twentieth century by and for fascism, it is now a monument for the new millennium; reinterpreted by a democratic society that believes in the values of participation, tolerance and respect for humanity." 80 By remaking this element of the cityscape into a site of knowledge production, it has become a site of resistance to social and ethnic categorization that would have been lost had the monument simply been taken down.

Political statements as well as media discourses, the opinions of public intellectuals, and the general reactions of the South Tyrolean population confirm that the process of historicization of the Victory Monument has been successful in reframing its earlier, controversial commemoration of violence. Most politicians have praised the "new" monument and the exhibition. For instance, Arno Kompatscher, the provincial president, spoke of a historical outcome that has managed to respect different sensibilities and free the monument from its ideological weight. According to Kompatscher, the exhibition gives people a space where they can "learn the historical bases of cohabitation and to build a future of peace." ${ }^{81}$ The Italian-speaking vice-president of the province, Christian Tommasini, stressed how "a monument that has in the past divided" the population became "a place that can unite," and described the exhibition as "a step toward cultural pluralism, plurilingualism and [...] European citizenship." ${ }^{82}$ Furthermore, Dario Franceschini, a former Italian Minister of Cultural Heritage, referred to the monument as a symbol of re-pacification and refusal of totalitarian regimes, pointing out that controversial memories are now used to highlight

\footnotetext{
78 Obermair, “Monument and City," 139.

79 Interview with Hannes Obermair, March 16, 2017.

80 Obermair, “Monument and City," 135.

81 Quoted in Redazione ANSA, “Kompatscher, da storicizzazione a normalizzazione," ANSA.it, July 21, 2014, http://www.ansamed.info/trentino/notizie/qualitaaltoadige/2014/07/21/kompatscher -da-storicizzazione-a-normalizzazione_7d0939ba-bd5c-4a44-bee1-b331479a4652.html.

82 Ibid.
} 
the progress of peaceful cohabitation in South Tyrol. ${ }^{83}$ Hans Heiss, from the South Tyrolean Green Party, added that the exhibition "makes the Victory Monument less poisonous." 84

Negative criticism - though focused on different issues - came predominantly from South Tyrolean German and Italian nationalist parties. Eva Klotz, a leader of the Süd-Tiroler Freiheit, a separatist, national-conservative political party, defined the monument as "an affront to all true anti-fascists and democrats" in that it "celebrates the symbolism of Fascism, renovated with an enormous sum of money." 85 The Victory Monument remains "the Fascist monument," "protected by high fences and CCTV; millions are spent for its upkeep." ${ }^{86}$ Along the same lines, Roland Lang, head of the Heimatbund, a patriotic separatist organization, stated that "a hidden museum in a cellar does not change the fact that day after day the inhabitants of Bozen have to live with a roman goddess of victory, who points an arrow toward Austria." ${ }^{87}$ According to Sven Knoll, a representative of the Süd-Tiroler Freiheit, without more radical intervention (i.e. its removal), the monument will always be a bulwark of nationalism and the exhibition hypostasizes that role. ${ }^{88}$ Therefore, Knoll says: "I will not visit this museum, I won't put foot into it. It doesn't interest me at all." 89

The criticisms of Italian nationalist right-wing parties focused on the LED ring, seen as an "indecent thing," an "eyesore" that should be removed, and a disfigurement of the monument. There were even threats of legal action against the "alteration of the material and historical characteristics" of the monument. ${ }^{90}$ However, the process of historicization, including the exhibition itself, was largely met with approval, even by one representative of Casa Pound, a neo-fascist party. ${ }^{91}$

83 Ibid.; Francesca Gonzato, "Il Monumento liberato dice addio all'ideologia," Alto Adige, July 22, 2014.

${ }^{84}$ Quoted in Ursula Lüfter, "Hans Heiss: Das ist kein Keller," Salto.bz, July 21, 2014, https://www .salto.bz/de/article/21072014/hans-heiss-das-ist-kein-keller.

85 Quoted in Susanne Pitro, "Die wahre Herausforderung steht noch bevor," Salto.bz, July 20, 2014, https://www.salto.bz/de/article/20072014/die-wahre-herausforderung-steht-noch-bevor.

${ }^{86}$ From the website of the Südtiroler Schützenbund, a folklorical patriotic association, https:// schuetzen.com/2016/05/01/das-siegesdenkmal-in-bozen/.

${ }^{87}$ Quoted in Pitro, "Die wahre Herausforderung."

88 See Gabriele Di Luca, "Il Monumento, lo storico e il patriota," Salto.bz, July 27, 2014.

${ }^{89}$ Quoted in Lüfter, "Hans Heiss."

90 Quoted in "L'anello sulla colonna. Ed è subito polemica," Alto Adige, July 22, 2014; Sarah Franzosini, "Südtiroler History X," Salto.bz, February 11, 2018, https://www.salto.bz/de/article /10022018/suedtiroler-history-x; see also Alto Adige, Monumento, esposto di Urzì: "Alterate le caratteristiche storiche," Alto Adige, July 22, 2014.

${ }^{91}$ Franzosini, "Südtiroler History X." 
The historicization of the monument was also positively received by many public intellectuals, the media and the general public. Historians and art experts commented approvingly on the exhibition. For example, according to South Tyrolean historian Carlo Romeo, the "light setting" of the exhibition succeeded in avoiding rhetorical banalization, in which the desire to symbolically weaken the monument would have come at the expense of proper, factual historicization. On the other hand, he observed, it also avoided a purely academic approach that ignored the political developments that led up to the installation of the permanent exhibition. It managed to communicate "the relationship between past and present," lifting the monument out of its isolation and making it part of the history and memory of Bolzano/Bozen and South Tyrol. ${ }^{92}$

Particularly significant in this context is the opinion of Vittorio Sgarbi, a prominent Italian art critic close to center-right parties. When a local rightwing politician called upon him to criticize the LED ring, the art critic instead approved of it, describing it as a "pop solution." ${ }^{33}$ Furthermore, various media accounts of the exhibition described it as a "high quality museum" that "marks a turning point and witnesses the change in relations between the South Tyrolean language groups,"94 that is "good for history and cohabitation,"95 is the "only way to deal with controversial past experiences" 96 and is a "re-aestheticization" that allows people to "distance themselves from a heritage that stings." 97 The addition of the LED ring was described as an "auto-critical historicization," 98 while the setting of the exhibition was considered the result of "a stroke of genius," because it allows citizens to question the monument, disempower it, and reflect on the future of such type of monuments. ${ }^{99}$ The 39th European Museum of the Year Award gave a "special commendation" to the exhibition and praised it for reintegrating a controversial monument and being a "highly

92 Carlo Romeo, "Il monumento svelato," August 14, 2014, http://www.carloromeo.it/index .php?option $=$ com_content $\& v i e w=$ article $\&$ id $=180:$ il - monumento-svelato $\&$ catid $=8 \&$ Itemid $=106$. See also interview with an expert on the art of the 1920s, Nicoloso: "Ben fatto, così fa meno paura," Alto Adige, July 23, 2014.

93 Paolo Campostrini, "Sgarbi: mi piace quell'anello. Operazione pop," Alto Adige, July 23, 2014.

${ }^{94}$ Gerhard Mumelter, "Metamorfosi di un monumento," Internazionale, April 23, 2014, www internazionale.it/opinione/gerhard-mumelter/2014/07/23/metamorfosi-di-un-monumento.

95 Marco Del Corona, "L'anello al naso che fa bene a Bolzano (e alla storia)," Corriere della sera, August 15, 2014.

96 Giovanni Belardelli, "Ribattezzare Ronchi dei Legionari?,” Corriere della sera, August 8, 2014.

97 Gabriele Di Luca, "Il Monumento (ri)estetizzato," Salto.bz, March 22, 2015.

${ }_{98}$ Leogrande, "La redenzione elettronica," 29.

99 Elfi Reiter, “Un abbecedario in marmo del fascismo," ilmanifesto, August 9, 2014, https://ilmanifesto .it/un-abbecedario-in-marmo-del-fascismo. 
courageous and professional initiative aimed to promote humanism, tolerance and democracy."100

Finally, most of the South Tyrolean general public has responded positively as well. The day of the exhibition's inauguration more than 3,500 people visited the monument and exhibition. ${ }^{101}$ By 2015 , the number of visitors had amounted to more than 55,000 , and it increased to more than 85,000 by July 2016 (an average of 1,500 visitors per month). In two years, 177 school classes (4,000 pupils) visited the monument. ${ }^{102}$ According to a survey conducted in December 2015, South Tyrolean residents and tourists positively welcomed the monument and the exhibition. Eighty-three percent of the respondents considered it a successful project and considered it to be something between a memorial and a historical monument. ${ }^{103}$

This view is well represented by the following remarks by an Italian-speaking woman during a public discussion of the exhibition a few days after its inauguration: "I never liked the monument and I never considered it an expression of my Italian-ness. The implemented project is the only way to stop persons who have until now identified with it from doing so." 104 In her analysis of the exhibition guest book, Adina Guarnieri points out that most visitors rate the exhibition positively because it neutralizes the monument. In contrast to the political level, where German-speaking politicians especially raised criticisms, Italian-speaking visitors make the most negative remarks. They complain, for example, about the LED ring and allege that the exhibition presents a false picture of history. ${ }^{105} \mathrm{It}$ should be noted that members of Italian-speaking groups have been reluctant to fully abandon the original meaning of the monument. Indeed, when in 2016 the mayor of Bolzano/Bozen mentioned the idea of changing the name of the monument (and the adjacent square) to Peace Monument and Peace Square, various representatives of the Italian-speakers opposed the idea. In a survey sponsored

\footnotetext{
${ }^{100}$ EMYA, Press Release, April 9, 2016, accessed February 20, 2018, http://www.monumenttovictory .com/fileadmin/user_upload/presse/_EMYA_2016_press_release_9_April_2016.pdf.

101 Gonzato, "Il Monumento liberato."

102 Data from Comune di Bolzano, "Premio Museo Europeo 2016," April 12, 2016, http:// www.comune.bolzano.it/stampa_context.jsp?ID_LINK $=426 \&$ area $=295 \&$ id_context $=28885 \&$ COL $0008=36$; and Alto Adige Innovazione, "Monumento alla Vittoria, un volume racconta la mostra," July 27, 2016, http://www.altoadigeinnovazione.it/monumento-alla-vittoria -presentato-il-volume-che-accompagna-la-mostra.

103 Alto Adige Innovazione, "Monumento alla Vittoria."

104 Quoted in Di Luca, "Il Monumento."

105 Quoted in Mara Mantinger, "Sieg und Frieden," barfuss, February 27, 2018, https://www.barfuss .it/leute/sieg-und-frieden.
} 
by the Italian newspaper Alto Adige, $78 \%$ of respondents rejected changing the name. ${ }^{106}$

In any event, the meaning of the monument has already been transformed. As pointed out by Obermair and Liliana Di Fede, the former secretary of the Partito Democratico, a name change is no longer needed because the monument "now belongs to everybody" and does not represent "that victory" but the victory of "the new South Tyrolean." 107 In other words, it "is already in substance a monument of peace." 108

\section{Going Forward: Difficult Pasts and New Citizens}

Traditionally, cultural heritage has been closely linked to the conservation and preservation of historical artifacts and monuments that are deemed to be of significance to a particular nation's history. The Council of Europe's 2005 Framework Convention on the Value of Cultural Heritage for Society (the Faro Convention) moves away from the previous place-centered understanding of heritage toward a people-centered perspective. The Convention emphasizes the idea of "heritage communities," understood as groups "which may not be linked by language, an ethnic tie or even a shared past, but are linked by a purposive commitment to specific heritages." It promotes the preservation of heritage as an inclusive, creative and transformative process. Focusing on the creation of a "common heritage of Europe," the Faro Convention also challenges the exclusionary nature of cultural heritage. At both the supra-national and the infra-national level, heritage can exist within, beyond and across nations. ${ }^{109}$

As explained above, the origins of the Victory Monument were anything but inclusive. Built to celebrate Italian rule, it was a physical manifestation of Fascist Italy's claims over the local population of South Tyrol and embodied the regime's aim to eradicate any language and culture other than the Italian one. In direct contrast to this homogenizing aim, the BZ '18-'45 exhibition embodies the spirit of the Faro Convention and emphasizes South Tyrol's heterogeneity by embracing and openly exploring pluralistic, often divergent interpretations of

\footnotetext{
106 "Monumento alla Pace il 78\% dei lettori dice «no»," Alto Adige, July 30, 2016.

107 Obermair, quoted in Paolo Campostrini, "Finalmente è caduto anche il nostro muro," Alto Adige, July 25, 2014.

108 Di Fede, quoted in Paolo Campostrini, "Sgarbi: «Pace sì, ma non al Monumento»," Alto Adige, July 29, 2016.

109 Fairclough, "New Heritage Frontiers," in Heritage and Beyond, ed. Council of Europe (Strasbourg: Council of Europe Publishing, 2009); see also Mitterhofer, "Beyond the Nation."
} 
South Tyrol's past and heritage. ${ }^{110}$ Members of both the Italian and the German political right have criticized the exhibition, which is testimony to its success, according to one of the historians in the Commission. ${ }^{111}$

The debates surrounding the Victory Monument have concerned primarily the feelings of the German and the Italian communities. However, as the percentage of people with completely foreign backgrounds is increasing in South Tyrol, the meaning and role of heritage may need to be re-defined. This applies particularly to sites like the Victory Monument, which play a key role - whether positive or negative - in the common heritage and collective identity of a community. The intimate relationship of these heritage sites to a circumscribed, territorially rooted past tends to exclude recent immigrants, whose pasts are rooted elsewhere and for whom a monument may carry little, if any, significance. ${ }^{112}$

To what extent have considerations about the inclusion of "new" South Tyroleans played a role in the making of the Victory Monument exhibition? According to Silvia Spada and Hannes Obermair, the exhibition's creators did not consider people with migrant backgrounds to be a target group. On the other hand, Spada says that there were no target groups categorized by language or ethnicity: "We didn't think about particular audiences when we were putting together the exhibition. The audience we had in mind was an abstract one. This helped us select themes and interpretations independently of ethno-linguistic categories." 113 According to the curators, the aim was to plan an exhibition that would speak to visitors independently of their origin and that would be accessible to anyone from a longtime resident to a casual German tourist, or from a local elementary school student to a newly arrived migrant.

With this "non-discriminating" approach, the exhibition applied the credo that heritage is not always inherited but can also be adopted ${ }^{114}$ - an important insight gained from the conceptual shift away from the idea of a single, cultural heritage. The curators' approach opens up the possibility for people to engage with heritage in fluid, ever-changing ways, without the need to belong to a community with an age-old connection to a particular heritage. ${ }^{115}$ Interpretations and approaches to the past do not necessarily need to be shared. They may be

\footnotetext{
110 Mitterhofer, "Beyond the Nation."

111 Interview with Hannes Obermair, March 16, 2017.

112 Mitterhofer, "Beyond the Nation."

113 Interview with Silvia Spada, March 14, 2017.

114 Fairclough, "New Heritage Frontiers," 35.

115 Mitterhofer, "Beyond the Nation."
} 
conflictual or dissonant, as this paper has shown, and they may be of varying (ir)relevance. What is important is that heritage is openly accessible to whoever may want to engage with it.

The transformation of the Victory Monument from a fenced-in monument, with which passers-by could only engage passively from the outside, to a monument-and-exhibition, which people could enter and actively reclaim the space, is a step toward democratization of what originally was a non-democratic heritage. The monument now invites people with or without shared roots to debate, disagree and creatively re-think the role of the past in the present.

\section{Conclusions}

Dealing with divided societies and ethnic tensions remains an enduring test for democracies. The task is not limited to designing institutions which organize government or share power among different ethnic segments of the population, or to recognizing minority rights and implementing policies to protect diversity. ${ }^{116}$ It also requires dealing with the cultural heritage of the region and the presence of symbols and cultural artifacts that may carry highly controversial meanings.

This article investigated the role of heritage in managing and negotiating interethnic relations and controversial memories. Focusing on the case of the Victory Monument in Bolzano/Bozen, the article sheds new light on the construction, contestation and reconstruction of controversial memories by physical landmarks. Heritage objects like the Victory Monument embody memories, provide cues for articulating identities and, in multiethnic societies, play a key role in shaping relationships between ethnicities and ethnic politics. Their management mirrors society's understanding of what it means to respect diversity. As shown in this article, the Victory Monument represented controversial meanings for decades and was at the center of tensions between the South Tyrolean linguistic communities. However, as has happened with the $B Z$ '18-'45 exhibition, it is at least possible to reframe such monuments as sites of reflection and mutual understanding, if not reconciliation. The permanent exhibition has transformed the Victory Monument from a symbol of division to a symbol of

116 For a review of this scholarship, see for example: Arend Lijphart, Democracy in Plural Societies: A Comparative Exploration (New Haven, CT: Yale University Press, 1977); Allison McCulloch and John McGarry, eds., Power-Sharing Empirical and Normative Challenges (London and New York: Routledge, 2017); Tove H. Malloy, ed., Minority Issues in Europe: Rights, Concepts, Policy (Berlin: Frank \& Timme, 2013). 
peace. Today, the monument no longer sparks tensions and discussions among the South Tyrolean linguistic communities. Furthermore, although not intentionally or directly, the exhibition has made the monument and its heritage accessible to the increasing number of people with migrant backgrounds who live in South Tyrol today.

This article does not intend to present the South Tyrolean experience as a model that can be copy-pasted in order to deal with contested cultural artifacts in other divided societies. The entire process of historicizing the Victory Monument, as well as the outcome of that process, is deeply embedded in the specific socio-political context of South Tyrolean society, in particular the relatively peaceful relations between the linguistic communities of the last few decades. Moreover, while the Victory Monument has been substantially transformed by the LED ring and the permanent exhibition, historicization of the many other Fascist relics in the region, and elsewhere in Italy, has only just begun. Most recently, for instance, a monumental bas-relief on an official building in Bolzano/ Bozen, which depicts Mussolini on horseback with the Fascist credo "believe, obey, fight," has been overlaid with a quotation from Hannah Arendt, "nobody has the right to obey." 117 Further research is necessary to analyze the mid- to long-term socio-political and cultural effects of the transformation of the controversial heritage of South Tyrol and to examine the South Tyrolean experience from a comparative perspective.

117 See The Bas-Relief: The History of Fascism in Images, http://www.basrelief-bolzano.com/en /content/the-bas-relief.html. 